\title{
Philippe Liverneaux, Christophe Chantelot: La traumatologie des parties molles de la main
}

\author{
Springer-Verlag France, 2012, 354 pp.; num. figs.; SoftCover, 132,00 €; Springer-Verlag \\ Paris, Berlin, Heidelberg, New York, Hong Kong, Londres, Milan, Tokyo ISBN:978-2- \\ 287-99067-0
}

\author{
Pierre Kehr • Vincent Travers
}

Received: 26 March 2014/ Accepted: 27 March 2014/Published online: 13 April 2014

(C) Springer-Verlag France 2014

A very interesting book, useful for all hand surgeons, but more for general surgeons or for departments of emergency. In fact, a book for all practicians seeing hand emergencies!

A total of 66 authors! All are French. The subject is the lesion of soft tissues on hand, and others books will be published about bone lesion and complex lesions.

First part of this book is about extensor system lesions. Many chapters for distinguishing all types of lesions. Indications and modality of treatment with many pictures and grafts are nicely presented. The operative techniques are very well explained.

A very good chapter about rehabilitation and indications of passive and dynamic post op splint.
Second part focuses on flexor system tendons lesions. On the same way, many chapters differentiate all types of lesions, indications, and explanations of surgical technique.

The others chapters are about nerve lesions and multitissular lesions of the hand.

At the end, some clinical cases, with for first of it a very pleasant MCQ. We regret that no such MCQ are proposed concerning all chapters. A good way to check your knowledge.

Conflict of interest None.

P. Kehr $(\bowtie) \cdot$ V. Travers

Strasbourg, France

e-mail: kehrpier@aol.com 